\title{
A PARTIAL SKELETON OF CHINIQUODON (CYNODONTIA, CHINIQUODONTIDAE) FROM THE BRAZILIAN MIDDLE TRIASSIC
}

\author{
TÉO VEIGA DE OLIVEIRA, CESAR LEANDRO SCHULTZ \& MARINA BENTO SOARES \\ Departamento de Paleontologia e Estratigrafia, IGEO, UFRGS, Cx. P. 15001, 91501-970, Porto Alegre, RS, Brasil. \\ tvoli@pop.com.br, cesar.schultz@ufrgs.br,marina.soares@ufrgs.br
}

\begin{abstract}
In this paper, we describe new postcranial remains of Chiniquodon $\mathrm{cf}$. C. theotonicus, a chiniquodontid cynodont from the Therapsid Cenozone, from the Santa Maria Formation, Middle Triassic of Southern Brazil. In the described specimen are preserved almost all presacral vertebrae, the sacral vertebrae, an incomplete pelvic girdle, the left femur, and two metapodials. Some of these bones show slight differences relative to those already described for $C$. theotonicus, especially in the femur and in the pelvic girdle. Since the species can actually include the materials attributed to the genera Probelesodon (except from P. sanjuanensis) and Belesodon, however, these differences may represent normal ontogenetic variation in the species rather than being of taxonomically diagnostic value.
\end{abstract}

Key words: Triassic, Santa Maria Formation, Brazil, Chiniquodontidae, Chiniquodon, postcranial skeleton.

RESUMO - Neste trabalho são descritos novos elementos pós-cranianos de Chiniquodon cf. C. theotonicus, um cinodonte chiniquodontídeo da Cenozona de Therapsida, da Formação Santa Maria, Triássico Médio do sul do Brasil. No espécime descrito estão preservadas quase todas as vértebras pré-sacrais, as vértebras sacrais, a cintura pélvica incompleta, o fêmur esquerdo e dois metapodiais. Alguns destes ossos apresentam pequenas diferenças em relação àqueles previamente descritos para $C$. theotonicus, especialmente no fêmur e na cintura pélvica. Uma vez que esta espécie pode, na realidade, incluir os materiais atribuídos aos gêneros Probelesodon (exceto de P. sanjuanensis) e Belesodon, estas diferenças podem representar variações ontogenéticas normais dentro de uma espécie e, assim, não ter grande valor taxonômico.

Palavras-chave: Triássico, Formação Santa Maria, Brasil, Chiniquodontidae, Chiniquodon, esqueleto pós-craniano.

\section{INTRODUCTION}

Chiniquodontidae (represented by Chiniquodon in the Figure 1A) represent one of the more distinguishable taxa of non-mammaliaform cynodonts from the South American Triassic (e.g. von Huene, 1935-1942; Romer, 1969a,b; Romer \& Lewis, 1973; Abdala, 1996; Martinez \& Forster, 1996; Abdala \& Giannini, 2002) as well as an isolated record from Namibia (Abdala \& Smith, 2007). These cynodonts are characterized by sectorial postcanine teeth, typical of the carnivorous forms, a greatly developed secondary osseous palate, long pterygoid flanges, and a very robust zygomatic arch, dorsally displaced and with a marked angle between maxilla and jugal in its anterior root (Abdala \& Giannini, 2002) (Figures 1B-C). In South America, they occur in the Middle Triassic of Brazil (von Huene, 1935-1942; Bonaparte, 1970, 1973; Teixeira, 1982; Abdala, 1996) and Middle (Romer, 1969a,b; Bonaparte, 1970, 1973; Romer \& Lewis, 1973; Abdala, 1996) and Late Triassic (Bonaparte, 1966a; Martinez \& Forster, 1996) of Argentina.

Although some authors have included Aleodon brachyrhamphus Crompton, 1955, Probainognathus jenseni Romer, 1970 (Hopson \& Kitching, 1972), and Cromptodon mamiferoides Bonaparte, 1972 (Hopson, 1991) within Chiniquodontidae and continue to treat the genera Belesodon and Probelesodon as valid (Hopson \& Kitching, 1972, 2001), here we adopt the position of Abdala \& Giannini (2002), who consider Chiniquodontidae to include only one genus and two species: Chiniquodon theotonicus von Huene, 1936 (a senior synonym of Belesodon magnificus von Huene, 1936, Probelesodon kitchingi Teixeira, 1982, P. lewisi Romer, 1969b, and P. minor Romer, 1973) and $C$. sanjuanensis (Martinez \& Forster, 1996) (initially described as $P$. sanjuanensis). C. theotonicus is the only species with known postcranial elements (von Huene, 1935-1942; Romer, 1969a; Romer \& Lewis, 1973; Abdala, 1996).

\section{GEOLOGICAL SETTING}

Zerfass et al. (2003) proposed the division of the sedimentary package deposited during the Ladinian-Rhaetic interval in the Rio Grande do Sul State in three depositional sequences (Figure 2A), named Santa Maria 1, 2, and 3 (respectively from the base to the top). The specimen here described, UFRGS PV-0146-T, was collected from an outcrop 
belonging to the basal portion of the Sequence Santa Maria 1 (Ladinian), composed of massive or finely laminated reddish mudstones and some carbonatic concretionary levels, corresponding to a floodplain facies (Machado, 2004; Rubert \& Schultz, 2004). This stratigraphic level bears the characteristic fossils of the Therapsid Cenozone, with the predominance of the dicynodont Dinodontosaurus (see von Huene, 1935-1942), followed by cynodonts (mainly Massetognathus) (Barberena, 1974, 1981b; Teixeira, 1987) and "rauisuchians" as Prestosuchus (see von Huene, 1935-1942). Other components of the fauna include rare rhynchosaurs (Schultz \& Langer, 2000), proterochampsids (cf. Chanaresuchus Dornelles, 1995) and procolophonids (Candelaria Cisneros et al., 2004). Among cynodonts, in addition to Chiniquodon theotonicus and Massetognathus ochagaviae Barberena, 1981b, the traversodontids Traversodon stahleckeri von Huene, 19351942 (see Barberena, 1981a) and Protuberum cabralensis Reichel, Schultz \& Soares, 2009 and the small probainognathian Protheriodon estudianti Bonaparte, Soares \& Schultz, 2006 are present in the Therapsid Cenozone.

The final portion of the Sequence Santa Maria 1 (still in Ladinian) shows a distinct fossiliferous assemblage named Traversodontid Biozone (Abdala et al., 2001) (Figure 2B). The Therapsid Cenozone is correlated to the Los Chañares Formation of Argentina (Rubert, 2003; Rubert \& Schultz, 2004), from where were also recovered dicynodonts (e.g. Dinodontosaurus; see Cox, 1968) and the cynodonts Massetognathus (Romer, 1967; Jenkins, 1970; Abdala \& Giannini, 2000) and Chiniquodon (Bonaparte, 1966a; Romer, $1969 \mathrm{~b}, 1973)$. Thus, it is possible to assign the Brazilian

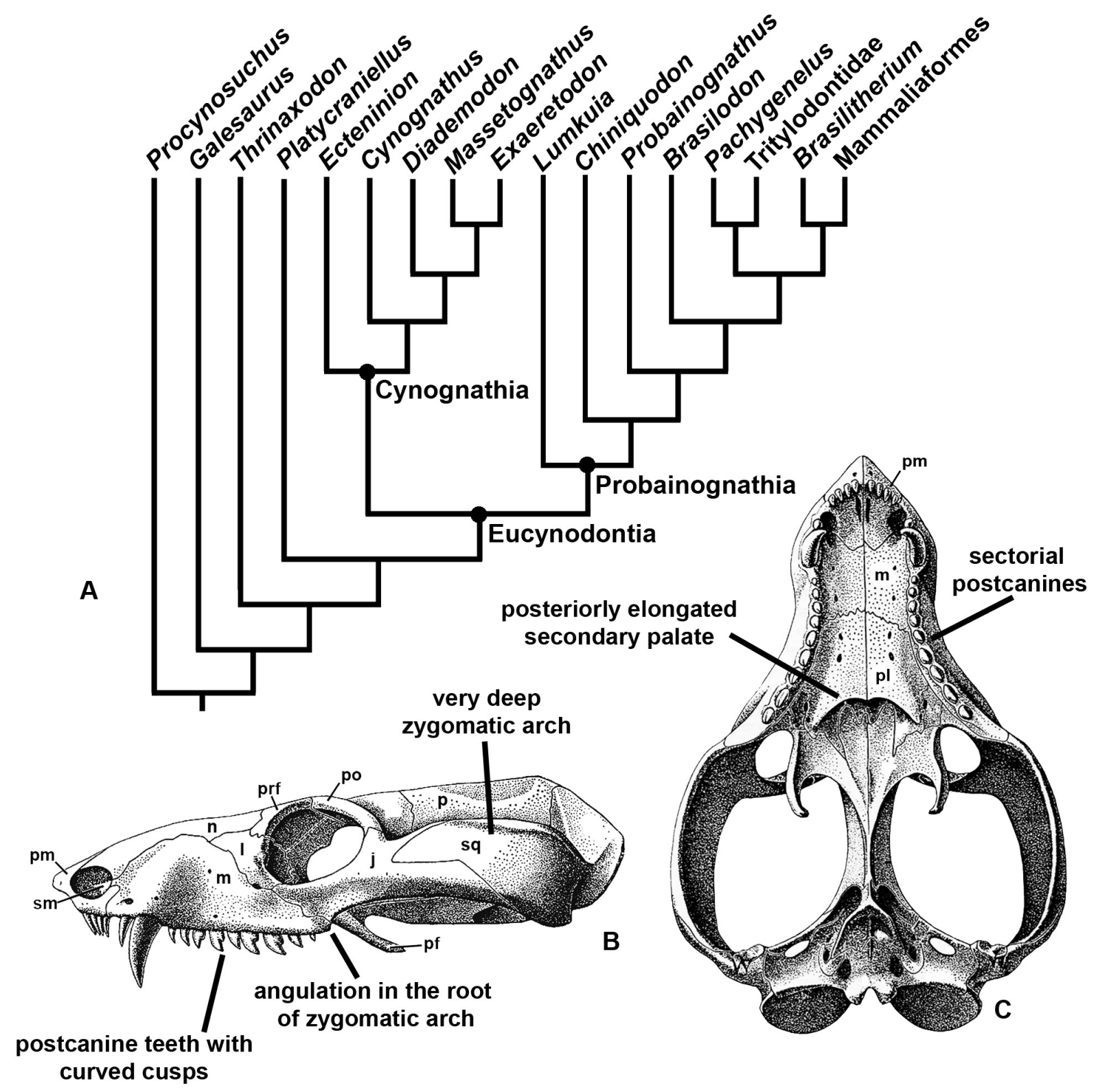

Figure 1. The Chiniquodontidae. A, simplified phylogeny of the Cynodontia, where the Chiniquodontidae are represented by Chiniquodon (modified from Abdala, 2007); B-C, general skull morphology of a chiniquodontid, in lateral and palatal views, respectively (modified from Romer, 1969b), with the main characters of the family labeled. Abbreviations are presented in Material section. 
Therapsid Cenozone an Early to Middle Chañarense age (Rubert \& Schultz, 2004) (Figure 2B).

\section{MATERIAL}

The specimen UFRGS PV-0146-T was collected in the municipality of Candelária, Rio Grande do Sul State, Brazil (Figure 3), approximately $200 \mathrm{~km}$ northwest of Porto Alegre, and consists of a cranium and mandible, twenty-six presacral vertebrae (probably lacking just the atlas), four sacral vertebrae, the incomplete right branch of the pelvic girdle articulated to the corresponding sacral ribs, the disarticulated left acetabular portion of the pelvic girdle, the left femur, two small rounded bones probably representing carpals and/or tarsals, two metapodials, and a series of fragmented elements including ribs and several undetermined bones.

Anatomical abbreviations. ac, acetabulum; asi, articular surface for the intercentra; ax, axis; cf, cranium fragment; $\mathbf{c p ,}$ coronoid process of dentary; d, dentary; e, epipterygoid; $\mathbf{f}$, frontal; fh, femoral head; gt, greater trochanter; itf, intertrochanteric fossa; j, jugal; l, lacrimal; lc, lateral condyle of femur; lt, lesser trochanter; $\mathbf{m}$, maxilla; mc, medial condyle of femur; mf, mandible fragment; $\mathbf{n}$, nasal; nf, notochordal fossa; o+ob, opisthotics and occipital bones; $\mathbf{p}$, parietal; pb, post-dentary bones; $\mathbf{p b s}+\mathbf{p r}+\mathbf{p t}$, parabasisphenoid, prootics and pterygoids; pf, pterygoid flange; pfs, paracanine fossa; pl, palatine; pm, premaxilla; po, postorbital; pof, popliteal fossa; pr, prootic; prf, prefrontal; ps, patellar sulcus; psv, presacral vertebra; q+q.j, quadrate and quadratojugal; sm, septomaxilla; sq, squamosal; sv, sacral vertebra.

Institutional abbreviations. UFRGS PV-T, Universidade Fe- deral do Rio Grande do Sul, Paleontologia de VertebradosTriássico, Porto Alegre, Rio Grande do Sul, Brasil.

\section{SYSTEMATIC PALEONTOLOGY}

Cynodontia Owen, 1861

Eucynodontia Kemp, 1982

Chiniquodontidae von Huene, 1936

Chiniquodon von Huene, 1936

Chiniquodon cf. C. theotonicus von Huene, 1936

(Figures 4-8)

\section{Description}

The specimen UFRGS PV-0146-T is assigned to the genus Chiniquodon due the presence of a greatly posteriorly developed secondary osseous palate and the marked angle between the anteroventral margin of the zygomatic arch and the maxillary zygomatic root (Figures 4A-C). In addition to these features, the snout is relatively short and stout and the zygomatic arch is very deep (Abdala \& Giannini, 2002). Unfortunately the crowns of the postcanine teeth are broken and their presumable sectorial morphology could not be observed.

Vertebrae. Here we assume that Chiniquodon cf. $C$. theotonicus had twenty-seven presacral vertebrae, a frequent condition among the non-mammaliaform cynodonts (Romer, 1956; Romer \& Lewis, 1973). The axis, the third, and the fourth vertebrae are articulated, but isolated from the remaining column. The fifth to twenty-sixth presacrals and the four sacrals are articulated. Several rib fragments are associated to the corresponding vertebrae.

In cynodonts, the limit between cervical and dorsal

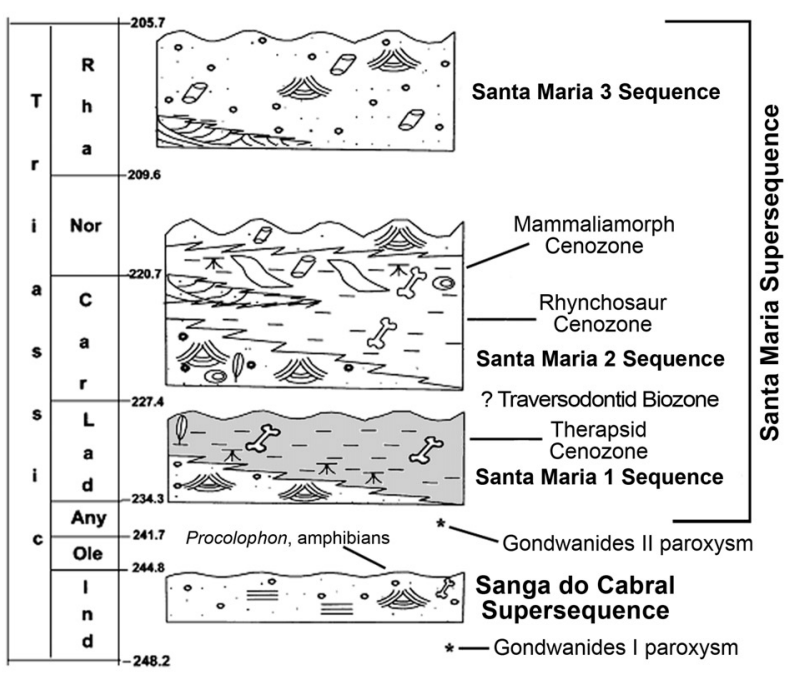

A

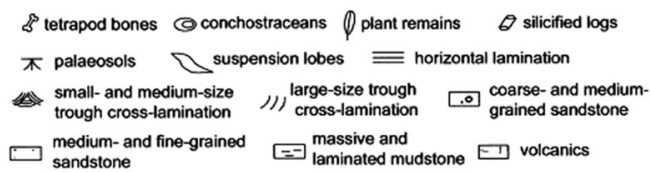

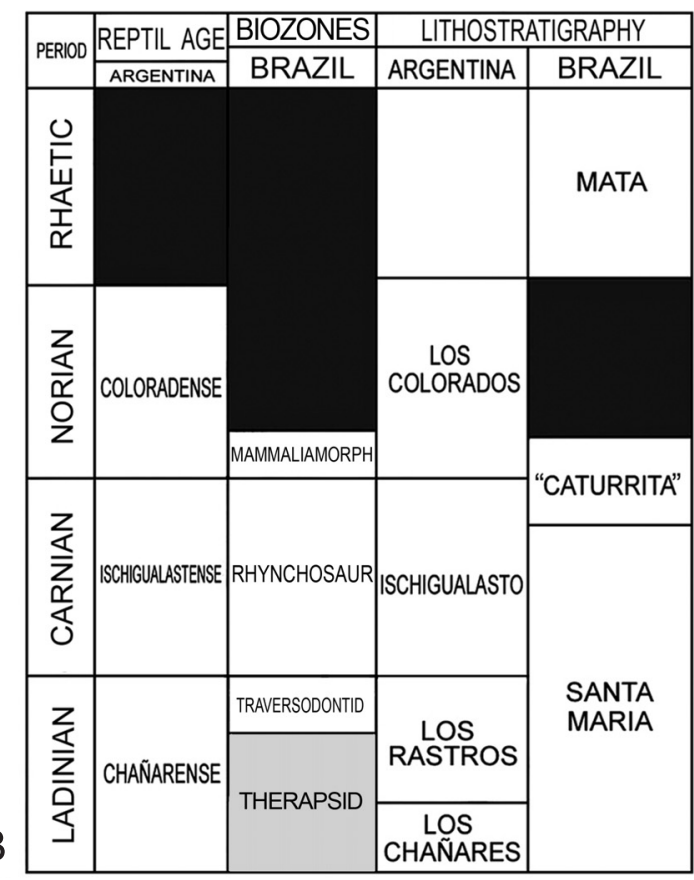

Figure 2. Stratigraphic context of Brazilian Triassic. A, sequence stratigraphy showing the Therapsid Cenozone (coloured) (modified from Zerfass et al., 2003); B, comparative bio- and lithostratigraphy between Brazilian and Argentine Triassic [modified from Rubert \& Schultz (2004) and Schultz \& Soares (2006)]. 
vertebrae is marked by the loss of intercentra, but as no intercentra are preserved in this specimen this distinction cannot be made. On the other hand, the distinction between thoracic and lumbar regions in the non-mammaliaform cynodonts is recognized by differences in the morphology of the ribs associated to the vertebrae. In several taxa [like in Thrinaxodon, Cynognathus, and others (see Jenkins, 1971)], the vertebrae are named thoracic when the diaphysis of the corresponding ribs runs beyond the costal plate or lumbar when the most terminal element of the rib is that plate (Brink, 1955; Jenkins, 1971). UFRGS PV-0146-T exhibits no costal specializations, so it is not possible to distinguish thoracic and lumbar vertebrae in this specimen. Thus, all the vertebrae here described will be named "presacral vertebrae".

The atlas was not preserved and the axis centrum is damaged (Figure 5). The centra of the following presacral vertebrae are very similar, approximately cylindrical, with salient anterior and posterior rims (Figures 5-7). The anterior or posterior faces are exposed in very few vertebral centra, but in those where it is possible a relatively deep notochordal fossa can be observed (Figure 5B) and very probably all the centra were amphicoelous, except that of the atlas. In the anterior portion of the ventral surface of the sixth to eighth presacral vertebrae there is a salience that could represent the attachment site for the corresponding intercentrum ('asi' in Figure 7), although none of these elements were recovered.

In general, the presacral neural spines are similar except for the axis, which exhibits a blade-like morphology with broad lateral surfaces and anteroposterior elongation (Figure 5A). The remaining neural spines are more slender and anteroposteriorly narrower (Figures 6-7). In the thirteenth presacral vertebra the neural spine becomes backwardly inclined about $25-30^{\circ}$ and this inclination is accentuated in the twentyfirst presacral, where the neural spine is inclined about $40-45^{\circ}$. Starting at this point, the neural spines become less inclined and in the twenty-sixth vertebra it is almost vertical (Figures 6-7).

The articular facets of the zygapophyses in the more anterior vertebrae are inclined at an angle about $45^{\circ}$; towards the sacrum the surface of prezygapophyses splits in two areas, one dorsally oriented and other medially directed (see 'psv20' in the Figure 6). Consequently, the postzygapophyses also split their articular facet in one surface ventrally directed and another one more lateral.

The transverse processes of the presacral vertebrae are
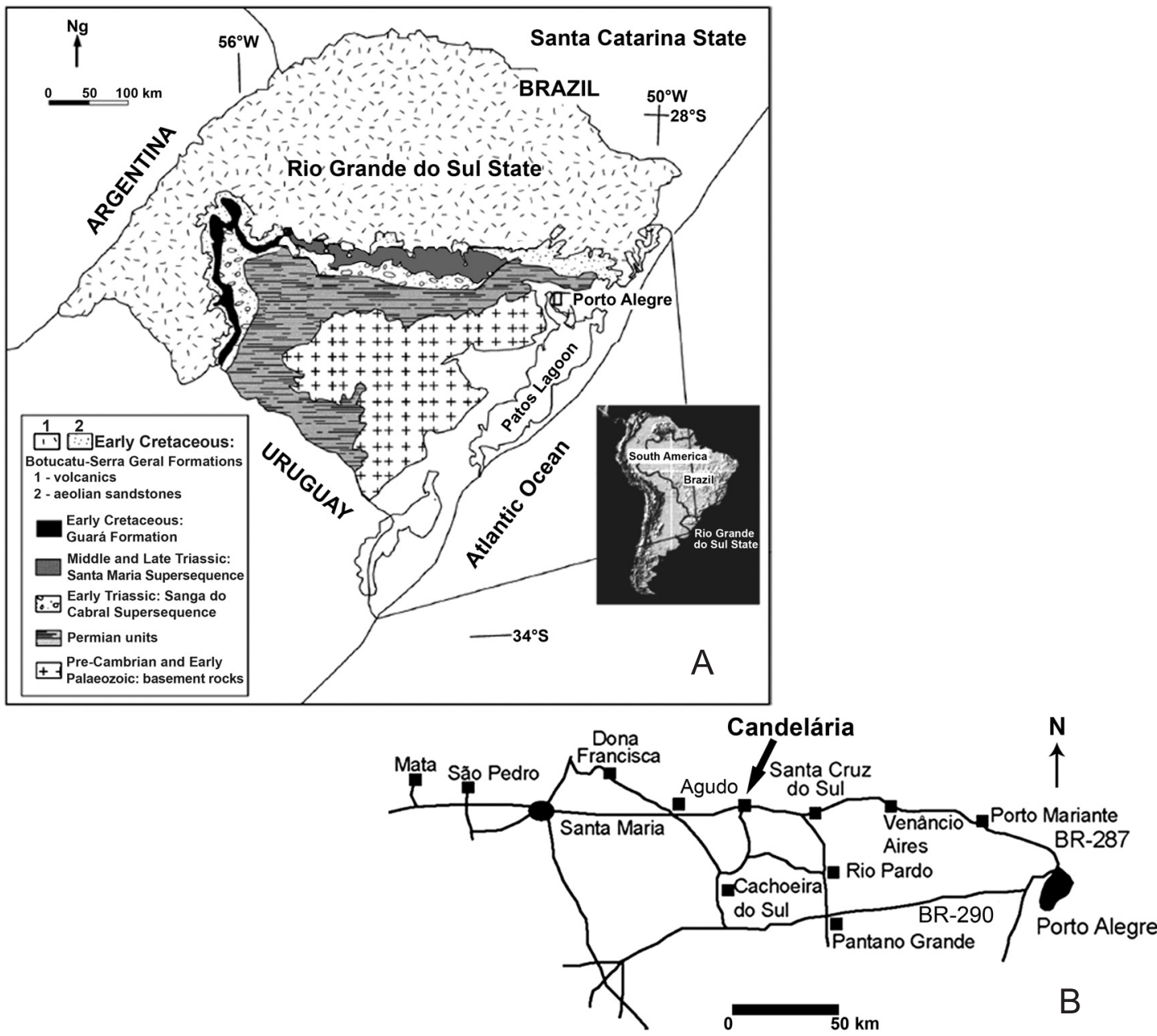

Figure 3. Geographic location of the study area. A, Rio Grande do Sul State location in South America with outcropping unities (Mesozoic rocks in solid grey); $\mathbf{B}$, road map with Candelária town pointed. 
short and stout (Figures 6-7) becoming gradually shorter up to the more posterior vertebrae. In the more anterior vertebrae these structures are backwardly directed about $30^{\circ}$, becoming less inclined in the posterior region of the column. In most of the presacral vertebrae it is possible to visualize the parapophyseal notches in the anterior and posterior borders of the vertebral centra. However, in some of the middle trunk vertebrae there is continuity between the diapophysis (in the transverse process) and the lateral surface of the anterior portion of the centrum, resulting in a single area to rib attachment, as a synapophysis. The synapophyses are anteriorly restricted by a descending anterior flange of the transverse process [like the condition described e.g. by Kemp (1980a) in Luangwa, although this author had not named the corresponding structure as synapophysis, by Reichel et al. (2009) in the more posterior presacral vertebrae of Protuberum].

There are four preserved sacral vertebrae, with the respective ribs associated to the right ilium (Figure 6). The fourth sacral rib is associated with the posterior end of iliac blade, which suggest that only four sacral vertebrae were present in this specimen, a relatively common number among non-mammaliaform cynodonts (e.g. Bonaparte, 1963; Romer, 1956). The sacral zygapophyses are firmly articulated to each other, maybe even fused, and probably the movements in this region were very restricted or nonexistent and the distal ends of sacral ribs were probably also synostosed. The centra of the sacral vertebrae do not differ significantly from those of presacral vertebrae and probably are also amphicoelous. The neural spines are quite vertical (Figure 6) and the transverse processes cannot be distinguished from the ribs. Ribs. There are not complete presacral ribs preserved, only some fragments attached to the vertebrae (Figures 6-7). The only ribs with remarkable features are the sacrals, with their obvious adaptations to ilium attachment (Figure 6). The first two ribs have an articular surface for the ilium approximately
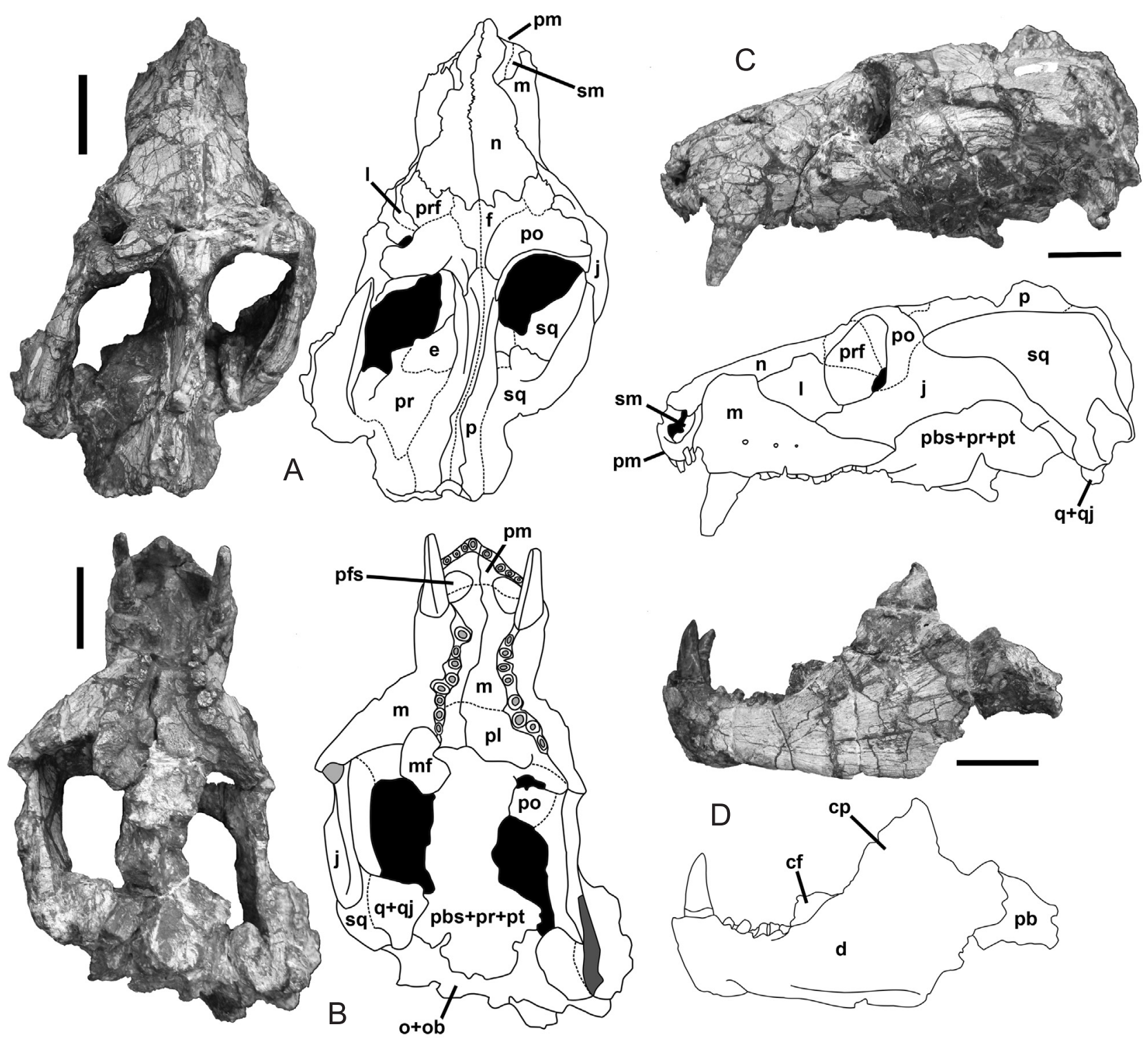

Figure 4. Skull of Chiniquodon cf. C. theotonicus (UFRGS PV-0146-T). A-C, cranium in dorsal, palatal and left lateral views, respectively; D, mandible in left lateral view. Abbreviations are presented in Material section. Scale bars $=5 \mathrm{~cm}$. 

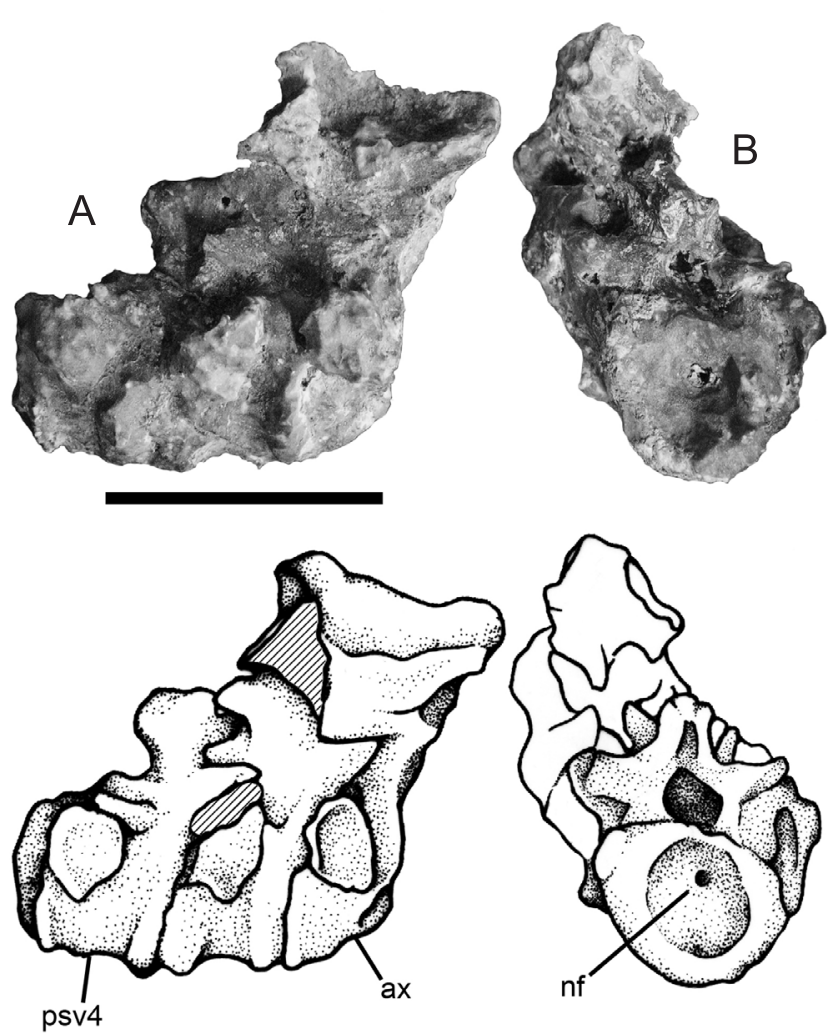

Figure 5. Presacral vertebrae 2 (axis) to 4 (UFRGS PV-0146-T), in right lateral (A) and caudal (B) (only fourth vertebra detailed) views. Abbreviations are presented in Material section. Scale bar $=5 \mathrm{~cm}$. quadrangular and facing dorsolaterally while in the third one this surface is more rectangular and faces more laterally; the same occurs in the fourth rib, although it is dorsoventrally narrower. Thus, the whole articular surface for ilium changes from an inclined orientation, in the first two sacral ribs, to a vertical one, more typical of non-mammaliaform cynodonts, in the two posterior ribs.

Pelvic girdle. The right branch of the pelvic girdle is the better preserved (Figure 7), while the left one had preserved only the acetabular portion and a little part of the ischium. The acetabulum is almost circular. The puboischiadic plate is poorly preserved, so the condition of the obturator foramen is not clear. The iliac blade seems very concave, but this is clearly a taphonomic distortion, once the column is curved at the sacral region and the ilium was pressed against the vertebrae. The preacetabular portion is more developed than the postacetabular one, although this latter is still great. The ilium bears an almost ventrally directed acetabular facet, with a supracetabular buttress dorsoanteriorly placed relative to the acetabulum. The ischium has an anterolaterally directed acetabular facet edged by a postacetabular buttress, although smaller than the supracetabular one. In cross-section the ischium is triangular, with an ischiatic crest dividing the lateral surface of the bone in two well defined areas, one dorsal and other ventrally directed. The better preserved portion of the pubis is the acetabular one, with a dorsoposteriorly directed acetabular facet.

Femur. In proximal view, the femoral head and the greater trochanter are continuous (Figure 8). The head is medially

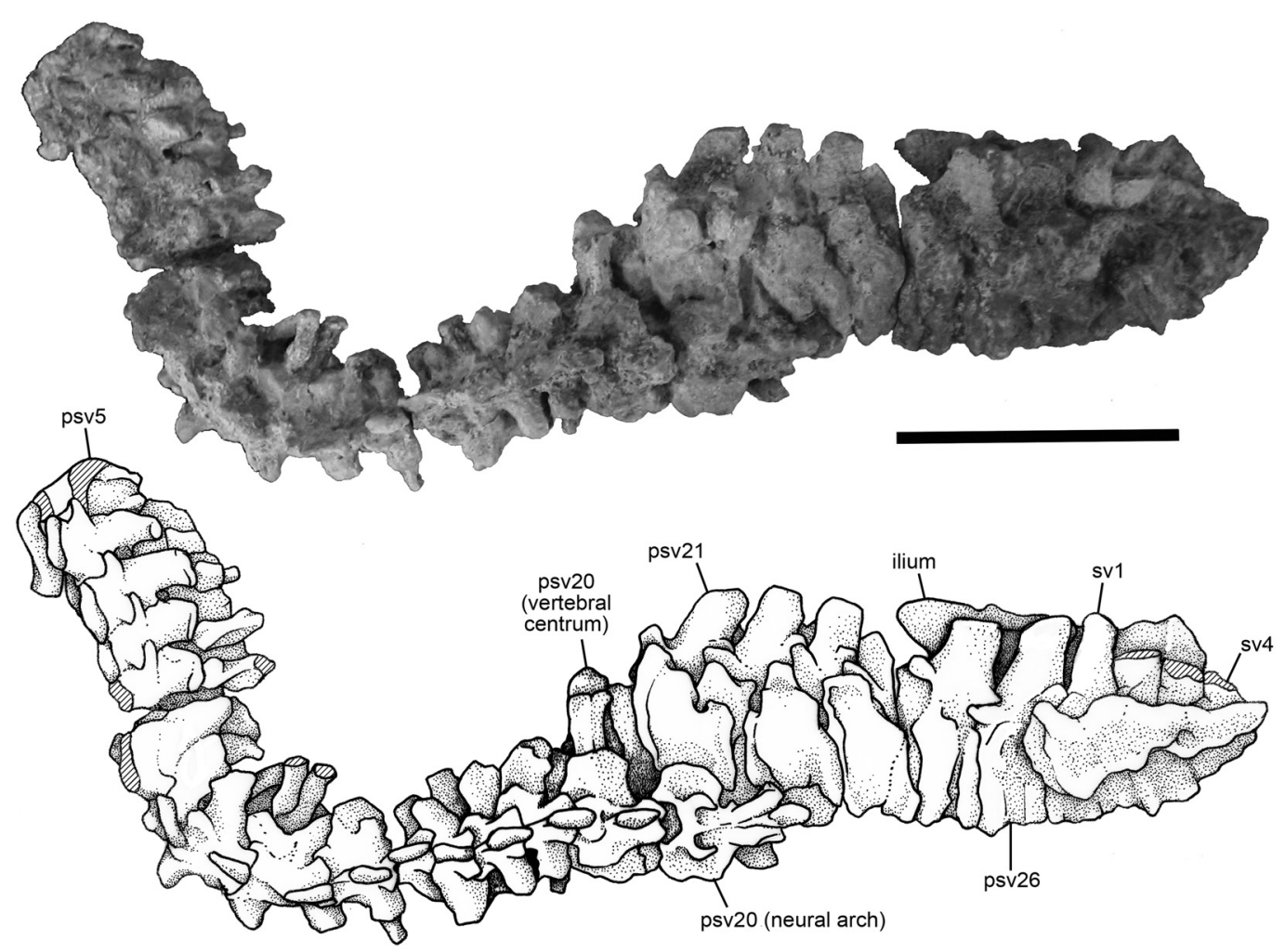

Figure 6. Presacral vertebrae 5 to 26, sacral vertebrae 1 to 4 and right pelvic bones (UFRGS PV-0146-T) in dorsal (presacral 5 to neural arch of presacral 20) and left lateral (the remaining bones) views. Abbreviations are presented in Material section. Scale bar $=10 \mathrm{~cm}$. 

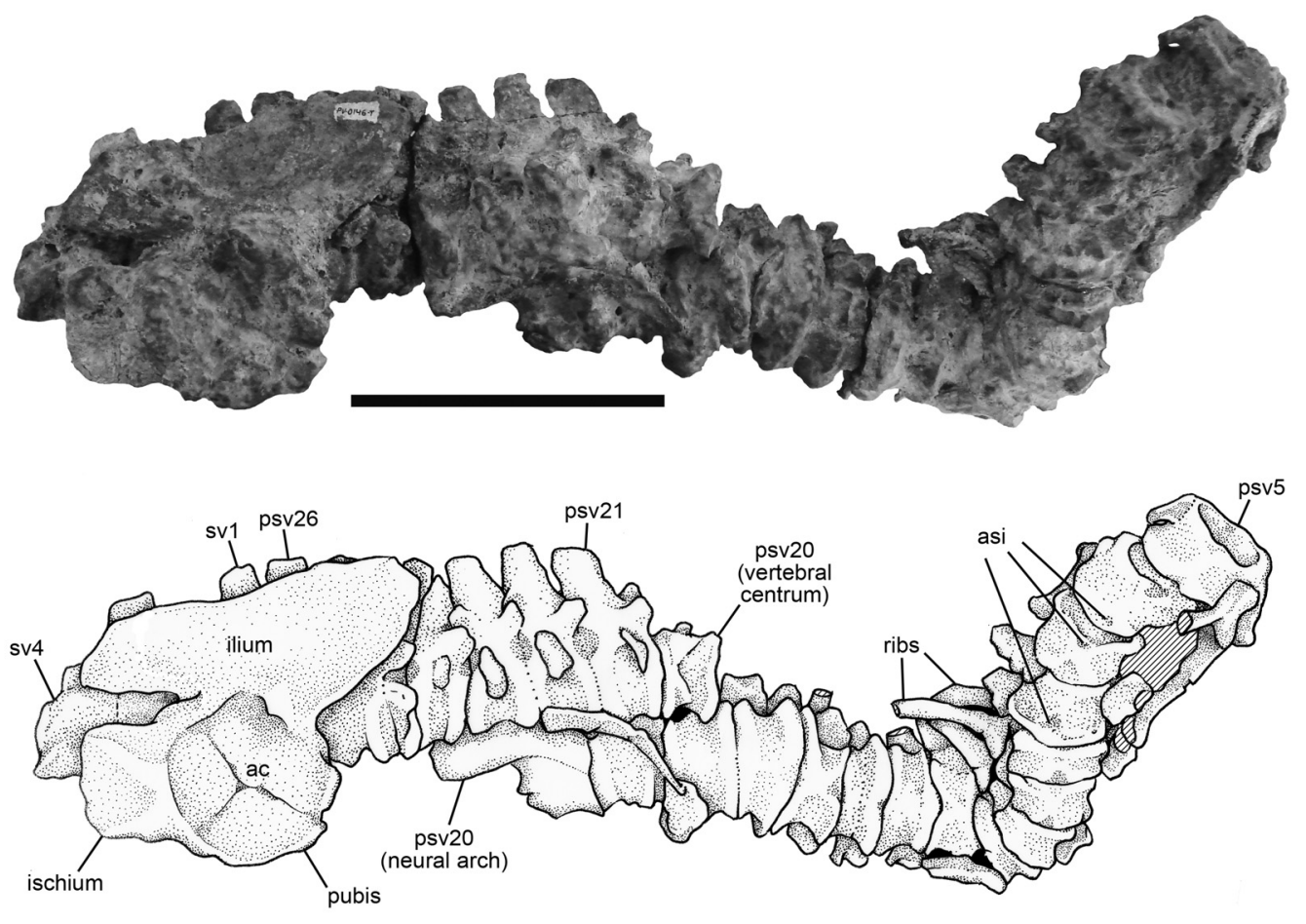

Figure 7. Presacral vertebrae 5 to 26, sacral vertebrae 1 to 4 and right pelvic bones (UFRGS PV-0146-T) in ventral (presacral 5 to neural arch of presacral 20) and right lateral (the remaining bones) views. Abbreviations are presented in Material section. Scale bar $=10 \mathrm{~cm}$.

and slightly dorsally displaced. Posteroventrally, there is a well developed intertrochanteric fossa; medially to this fossa is the lesser trocanter. Ventrodistally, there is a shallow popliteal fossa. The medial condyle is more posteroventrally projected than the posterior one. The condylar articular surface forms an angle about $45^{\circ}$ relative to the long axis of femur, a generic adaptation for a semi-upright posture in the hind limbs (Jenkins, 1971).

\section{DISCUSSION}

Vertebrae. In the more anterior presacral vertebrae, as in the sixth one, are visible two small longitudinal ventral keels. Most other non-mammaliaform cynodonts [e.g. Thrinaxodon, Galesaurus and Cynognathus (Jenkins, 1971)], have no keel in this region, while Oligokyphus (Kühne, 1956) has a single keel, as occurs in the seventh presacral vertebrae of the specimen here described. These anterior vertebrae do not differ from those of the middle and posterior regions of the trunk, without the anteroposterior shortening observed in more advanced cynodonts, such as Therioherpeton and Prozostrodon (Bonaparte \& Barberena, 2001) and mammaliaforms (Kielan-Jaworowska et al., 2004).

None of the presacral vertebrae are expanded at the apex of their neural spines, unlike the condition in, e.g. in Exaeretodon frenguellii Cabrera, 1943 (see Bonaparte, 1963) and Kayentatherium (Lewis, 1986; Sues \& Jenkins, 2006). Besides, the specimen UFRGS PV-0146-T [as well as Procynosuchus (Kemp, 1980b), Exaeretodon (Bonaparte, 1963; Oliveira, 2006; Oliveira et al., 2007) and Probainognathus (Abdala, 1996)] also lack the anapophyses assigned for cynodonts as Thrinaxodon (Jenkins, 1971), Diademodon (Brink, 1955), and Oligokyphus (Kühne, 1956). The presacral vertebrae do not differ significantly from those described by von Huene (1935-1942) for C. theotonicus.

As mentioned above, the four sacral vertebrae of the specimen UFRGS PV-0146-T represent a frequent condition among the non-mammaliaform cynodonts (Romer, 1956; Kielan-Jaworowska et al., 2004), like occur e.g. in Diademodon (Gow \& Grine, 1979), Therioherpeton (Bonaparte \& Barberena, 2001), Kayentatherium (Lewis, 1986) and Oligokyphus (Kühne, 1956). In spite of this, Romer \& Lewis (1973) claims that Chiniquodon has actually five sacral vertebrae, which could be a result of the incorporation of a lumbar or a caudal vertebra to the sacrum (Bonaparte, 1963; Oliveira et al., 2006), probably in senile individuals. On the other hand, von Huene (1935-1942) attributed to Chiniquodon only three sacral vertebrae.

There are no significant differences among the sacral neural spines relative to those of the posterior presacral vertebrae, unlike the described e.g. for Thrinaxodon and Cynognathus (Jenkins, 1971), Massetognathus (Jenkins, 1970), and Exaeretodon (Bonaparte, 1963; Oliveira, 2006; Oliveira et al., 2007), which have shorter and anteroposterior narrower sacral spines.

Ribs. In the preserved presacral ribs of the specimen UFRGS PV-0146-T there is no costal specialization, like in all known probainognathian (Hopson \& Kitching, 2001). On the other hand, several species of non-probainognathian cynodonts (but not all of them) show expanded ribs [e.g. Galesaurus (Parrington, 1934), Thrinaxodon (Jenkins, 1971), Diademodon (Brink, 1955), Cynognathus (Broom, 1914), as well as some 

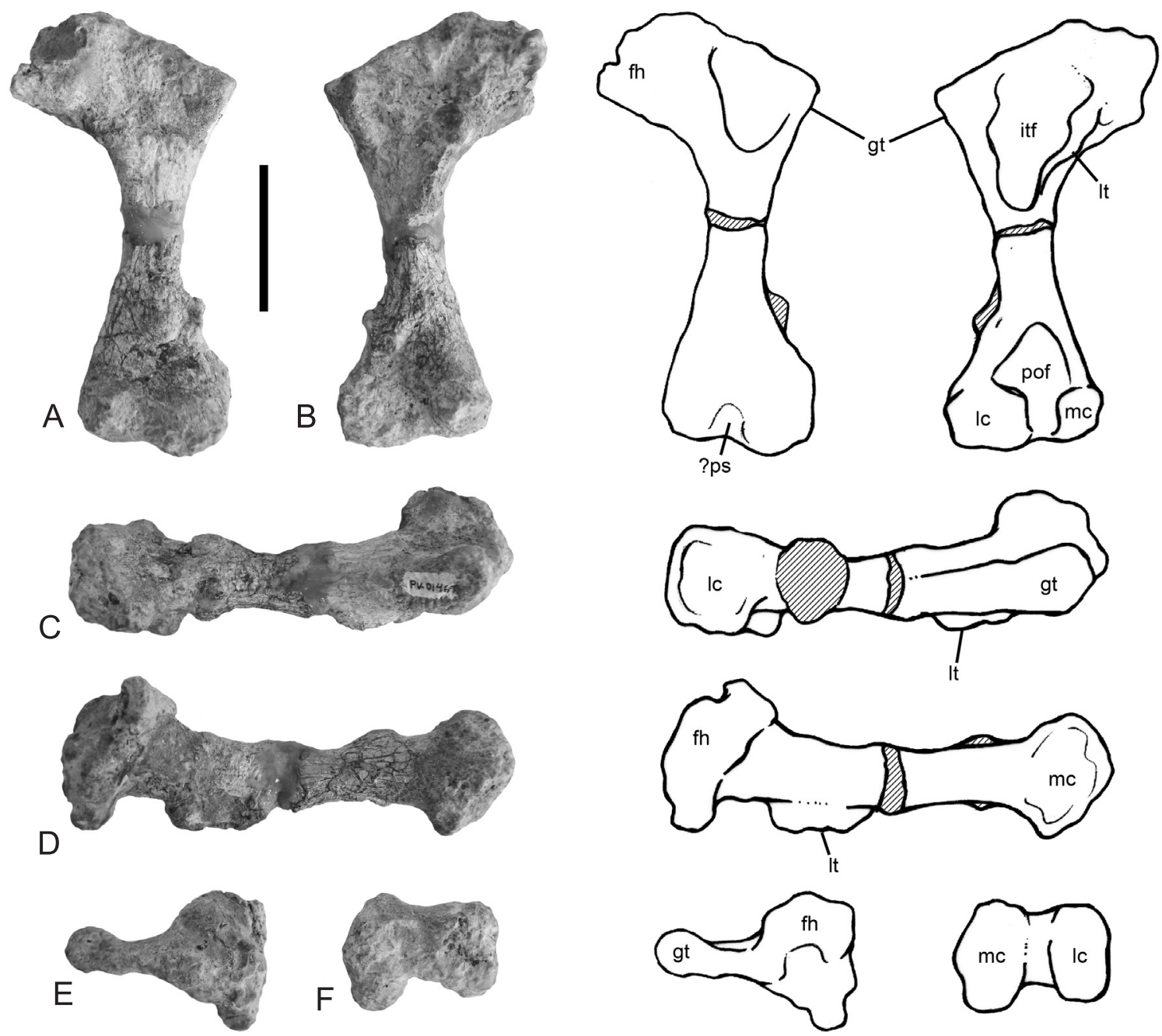

Figure 8. Left femur (UFRGS PV-0146-T) in cranial (A), caudal (B), lateral (C), medial (D), proximal (E) and distal (F) views. Abbreviations are presented in Material section. Scale bar $=5 \mathrm{~cm}$.

traversodontids (Bonaparte, 1966b, 1970; Jenkins, 1970; Kemp, 1980a)].

In the sacral ribs the most remarkable feature is the change of the dorsolateral inclination of the articular surface for the ilium in the anterior ribs to a more lateral orientation in the two more posterior ribs. This morphology is similar to that observed in Exaeretodon (Bonaparte, 1963; Oliveira, 2006; Oliveira et al., 2007) and is explained by the corresponding morphology of the medial face of the iliac blade, which is medioventrally directed in its anterior half and shifts medially in the posterior region.

Pelvic girdle. The specimen UFRGS PV-0146-T shows a pelvic morphology similar to Cynognathus and Diademodon (Jenkins, 1971), although its ilium has a slightly greater preacetabular portion than the African taxa. The pelvic girdle of Chiniquodon presented by von Huene (1935-1942) has a slightly more elongated postacetabular region. This condition differs drastically from that observed in several traversodontids, e.g. Exaeretodon (Bonaparte, 1963) and Menadon (Kammerer et al., 2008), where the postacetabular area of the iliac blade is greatly reduced or in some more advanced cynodonts, such as Prozostrodon (Bonaparte \& Barberena, 2001), where this region is completely absent.
Femur. The femur shows similarities with Cynognathus and Diademodon (Jenkins, 1971), like the continuity between the head and the greater trochanter, the relatively deep ventral intertrochanteric fossa, the presence of a smooth crest arising in the lesser trocanter that runs up to the lateral condyle, and a more ventrally projected anterior condyle. The first of these characters also appears in several cynodonts, such as Exaeretodon (Bonaparte, 1963) and Therioherpeton (Bonaparte \& Barberena, 2001). The referred crest was assigned also for Exaeretodon (Bonaparte, 1963) and Massetognathus (Jenkins, 1970).

The femur UFRGS PV-0146-T is more advanced than those of e.g. Procynosuchus (Kemp, 1980b), Thrinaxodon (Jenkins, 1971), and Massetognathus (Jenkins, 1970), i.e., is proportionally more slender and long and has its head more medially displaced. On the other hand, it is considerably more primitive relative to the advanced pattern observed in e.g. Oligokyphus (Kühne, 1956) and Morganucodon (Jenkins \& Parrington, 1976), where the femur is even more slender and the head is very spherical and separated from the great trocanter by a notch. The femur is similar to those described by von Huene (1935-1942) for other specimens of Chiniquodon. 


\section{CONCLUSIONS}

Some authors had described postcranial remains of the genera Belesodon (von Huene, 1935-1942), Probelesodon (Romer \& Lewis, 1973) and Chiniquodon (von Huene, 19351942; Romer, 1969a) where was possible to visualize some differences between these taxa. However, after the critical evaluation of the taxonomic status of the species included in these genera, presented by Abdala \& Giannini (2002), and accepting the assumption that these three correspond actually to a single genus, Chiniquodon, and representing distinct ontogenetic stages of a single species, $C$. theotonicus, those postcranial differences must be reevaluated. Two hypotheses could be presented: the differences could be consequence of individual (intraspecific) variation, once there are very few specimens to establish a consistent morphological pattern to the species, or they actually reflect distinct ontogenetic stages represented in the fossil record. The specimen UFRGS PV-0146-T show some differences relative to the postcranial remains already described as slight modifications in the pelvic and femoral morphology, which can be attributed to the "normal" range of variation of the species.

\section{ACKNOWLEDGMENTS}

We thanks to CAPES (Coordenação de Aperfeiçoamento de Pessoal de Nível Superior) and CNPq (Conselho Nacional de Desenvolvimento Científico e Tecnológico) for funding this study. We also thank two anonymous referees who reviewed an early draft of this paper.

\section{REFERENCES}

Abdala, F. 1996. Los Chiniquodontoideos (Synapsida, Cynodontia) Sudamericanos. Universidad Nacional de Tucumán, PhD Thesis, $381 \mathrm{p}$.

Abdala, F. 2007. Redescription of Platycraniellus elegans (Therapsida, Cynodontia) from the Lower Triassic of South Africa, and the cladistic relationships of eutheriodonts. Palaeontology, 50(3):591-618.

Abdala, F. \& Giannini, N.P. 2000. Gomphodont cynodonts of the Chañares Formation: the analysis of an ontogenetic sequence. Journal of Vertebrate Paleontology, 20(3):501-506.

Abdala, F. \& Giannini, N.P. 2002. Chiniquodontid cynodonts: systematic and morphometric considerations. Palaeontology, 45(6): 1151-1170.

Abdala, F. \& Smith, R.M.H. 2007. Gondwanan Middle Triassic cynodonts from Namibia. Palaeontologia Africana, 42:117.

Barberena, M.C. 1974. Contribuição ao Conhecimento dos Cinodontes Gonfodontes (Cynodontia, Tritylodontoidea) do Brasil. Universidade Federal do Rio Grande do Sul, Tese de Livre Docência, 194 p.

Barberena, M.C. 1981a. Novos materiais de Traversodon stahleckeri da Formação Santa Maria (Triássico do Rio Grande do Sul). Pesquisas, 14:149-162.

Barberena, M.C. 1981b. Uma nova espécie de Massetognathus (Massetognathus ochagaviae, sp.nov.) da Formação Santa Maria, Triássico do Rio Grande do Sul. Pesquisas, 14:181-195.

Bonaparte, J.F. 1963. Descripción del esqueleto postcraneano de Exaeretodon. Acta Geológica Lilloana, 4:5-52.

Bonaparte, J.F. 1966a. Chiniquodon Huene (Therapsida -
Cynodontia) en el Triásico de Ischigualasto, Argentina. Acta Geologica Lilloana, 8:5-31.

Bonaparte, J.F. 1966b. Una nueva "fauna" Triásica de Argentina (Therapsida: Cynodontia Dicynodontia). Consideraciones filogenéticas y paleobiogeográficas. Ameghiniana, 4(8):243-296.

Bonaparte, J.F. 1970. Annotated list of the South American Triassic tetrapods. In: GONDWANA SYMPOSIUM, 2, 1970. Proceedings and Papers, Pretoria, International Union of Geological Sciences, p. 665-682.

Bonaparte, J.F. 1972. Cromptodon mamiferoides gen. et sp. nov., Galesauridae de la Formación Río Mendoza, Mendoza, Argentina. (Therapsida - Cynodontia). Ameghniana, 9(4):343-353.

Bonaparte, J.F. 1973. Edades/réptil para el Triásico de Argentina y Brasil. In: CONGRESO GEOLÓGICO ARGENTINO, 5, 1973. Actas, vol. 3, Buenos Aires, Asociación Geológica Argentina, p. 93-129.

Bonaparte, J.F. \& Barberena, M.C. 2001. On two advanced carnivorous cynodonts from the late Triassic of Southern Brazil. Bulletin of the Museum of Comparative Zoology, 156(1):59-80.

Bonaparte, J.F.; Soares, M.B. \& Schultz, C.L. 2006. A new nonmammalian cynodont from the Middle Triassic of Southern Brazil and its implications for the ancestry of mammals. The Triassic-Jurassic Terrestrial Transition, New Mexico Museum of Natural History and Science Bulletin, 37:599-607.

Brink, A.S. 1955. A study on the skeleton of Diademodon. Palaeontologia Africana, 3:3-39.

Broom, R. 1914. On the theriodonts in the Albany Museum. Records of the Albany Museum, 1(2):82-87.

Cabrera, A. 1943. El primer hallazgo de terápsidos en la Argentina. Notas del Museo de La Plata, 8:317-333.

Cisneros, J.C.; Damiani, R.; Schultz, C.; Rosa, A.; Schwanke, C.; Neto, L.W. \& Aurelio, P.L.P. 2004. A procolophonid reptile with temporal fenestration from the Middle Triassic of Brazil. Proceedings of the Royal Society of London, B, 271:1541-1546.

Cox, C.B. 1968. The Chañares (Argentina) Triassic reptile fauna. IV. The dicynodont fauna. Breviora, 295:1-27.

Crompton, A.W. 1955. On some Triassic cynodont from Tanganyika. Proceedings of the Zoological Society of London, 125:617-669.

Dornelles, J.E.F. 1995. Um tecodonte proterosuchídeo (Chanaresuchus sp.) do Triássico do Rio Grande do Sul. Comunicações do Museu de Ciências e Tecnologia UBEA/PUCRS (Série Ciências da Terra), 1:63-68.

Gow, C.E. \& Grine, F.E. 1979. An articulated skeleton of a small individual of Diademodon (Therapsida; Cynodontia). Palaeontologia Africana, 22:29-34.

Hopson, J.A. 1991. Systematics of the nonmammalian Synapsida and implications for patterns of evolution in Synapsida. In: H.D. Schultze \& L. Trueb (eds.) Origin of the higher groups of tetrapods: controversy and consensus, Comstock Publishing Associates, p. 635-693.

Hopson, J.A. \& Kitching, J.W. 1972. A revised classification of cynodonts (Reptilia: Therapsida). Palaeontologia Africana, 14:71-85.

Hopson, J.A. \& Kitching, J.W. 2001. A probainognathian cynodont from South Africa and the phylogeny of nonmammalian cynodonts. Bulletin Museum of Comparative Zoology, 156(1):5-35.

Huene, F.F. von. 1935-1942. Die Fossilen Reptilien des Sudamerikanischen Gondwanalandes: Ergebnisse der Sauriergrabuiigen in Südbrazilien 1928/1929. Munich, Beck'sche Verlagsbuchhandlung, 332 p.

Huene, F.F. von. 1936. Lieferung 2. Cynodontia. In: F.F. von Huene (ed.) Die fossilen Reptilien des Südamerikanischen Gondwanalandes. Ergebnisse der Sauriergrabungen in 
Südbrasilien 1928/29. Beck'sche Verlagsbuchhandlung, p. $83-$ 160.

Jenkins, F.A. Jr. 1970. The Chañares (Argentina) Triassic reptile fauna VII. The postcranial skeleton of the traversodontid Massetognathus pascuali (Therapsida, Cynodontia). Breviora, 352:1-28.

Jenkins, F.A. Jr. 1971. The Postcranial Skeleton of African Cynodonts: Problems in the Early Evolution of the Mammalian Postcranial Skeleton. Peabody Museum of Natural History, 216 p. (Bulletin 36).

Jenkins, F.A. Jr. \& Parrington, F.R. 1976. The postcranial skeletons of the Triassic mammals Eozostrodon, Megazostrodon and Erythrotherium. Philosophical Transactions of the Royal Society of London, Series B, Biological Sciences, 273:387-431.

Kammerer, C.F.; Flynn, J.J.; Ranivoharimanana, L. \& Wyss, A. 2008. New material of Menadon besairiei (Cynodontia: Traversodontidae) from the Triassic of Madagascar. Journal of Vertebrate Paleontology, 28(2):445-462.

Kemp, T.S. 1980a. Aspects of the structure and functional anatomy of the Middle Triassic cynodont Luangwa. Journal of Zoology, 191:193-239.

Kemp, T.S. 1980b. The primitive cynodont Procynosuchus: structure, function and evolution of the postcranial skeleton. Philosophical Transactions of the Royal Society of London, 288:217-258.

Kemp, T.S. 1982. Mammal-like reptiles and the origin of mammals. New York, Academic Press, 362 p.

Kielan-Jaworowska, Z.; Cifelli, R.L. \& Luo, Z.-X. 2004. Mammals from the age of dinosaurs: origins, evolution and structure. New York, Columbia University Press, 630 p.

Kühne, W.G. 1956. The Liassic Therapsid Oligokyphus. London, British Museum (Natural History), 149 p.

Lewis, G.E. 1986. Nearctylodon broomi the first neartic tritylodont. In: N. Hotton III; P.D. MacLean; J.J. Roth \& C. Roth (eds.) The Ecology and Biology of Mammal-like Reptiles. Smithsonian Institution Press, p. 295-303.

Machado, C.B. 2004. Concentrações fossilíferas controladas pelo nível freático: um modelo tafonômico para reconstruções paleoambientais. Programa de Pós-graduação em Geociências, Universidade Federal do Rio Grande do Sul, Dissertação de Mestrado, 73 p.

Martinez, R.N. \& Forster, C.A. 1996. The skull of Probelesodon sanjuanensis, sp. nov., from the Late Triassic Ischigualasto Formation of Argentina. Journal of Vertebrate Paleontology, 16(2):285-291.

Oliveira, T.V. 2006. Descrição osteológica de materiais póscranianos de dois cinodontes não-mamalianos do Meso/ Neotriássico (Formação Santa Maria, Bacia do Paraná) do Rio Grande do Sul, Brasil. Programa de Pós-graduação em Geociências Universidade Federal do Rio Grande do Sul, Dissertação de Mestrado, 137 p.

Oliveira, T.V.; Schultz, C.L. \& Soares, M.B. 2006. Discusión sobre la ocurrencia de homoplasias en el esqueleto postcraneano de cinodontes no mamalianos (Therapsida, Cynodontia). Ameghiniana, 43(4-Suplemento):57R-58R.

Oliveira, T.V.; Schultz, C.L. \& Soares, M.B. 2007. O esqueleto pós-craniano de Exaeretodon riograndensis Abdala et al. (Cynodontia, Traversodontidae), Triássico do Brasil. Revista Brasileira de Paleontologia, 10(2):79-94.

Owen, R. 1861. Palaeontology, or a systematic summary of extinct animals and their geologicalrRelations. Edinburgh, Adam and Charles Black, 463 p.
Parrington, F.R. 1934. On the cynodont genus Galesaurus, with a note on the functional significance of the changes in the evolution of the theriodont skull. Annals and Magazine of Natural History, 10:38-67.

Reichel, M.; Schultz, C.L. \& Soares, M.B. 2009. A new traversodontid (Therapsida, Eucynodontia) from the Middle Triassic Santa Maria Formation of Rio Grande do Sul, Brazil. Palaeontology, 52(1):229-250.

Romer, A.S. 1956. Osteology of the Reptiles. Chicago, The University of Chicago Press, 772 p.

Romer, A.S. 1967. The Chañares (Argentina) Triassic Reptile Fauna. III. Two New Gomphodonts, Massetognathus pascuali and $M$. teruggii. Breviora, 264:1-25.

Romer, A.S. 1969a. The Brazilian Triassic cynodont reptiles Belesodon and Chiniquodon. Breviora, 332:1-16.

Romer, A.S. 1969b. The Chañares (Argentina) Triassic reptile fauna V. A new chiniquodontid cynodont, Probelesodon lewisi cynodont ancestry. Breviora, 333:1-24.

Romer, A.S. 1970. The Chañares (Argentina) Triassic reptile fauna. VI. A chiniquodontid cynodont with an incipient squamosaldentary jaw articulation. Breviora, 334:1-18.

Romer, A.S. 1973. The Chañares (Argentina) Triassic reptile fauna. XVIII. Probelesodon minor, a new species of carnivorous cynodont; family Probainognathidae nov. Breviora, 401:1-4.

Romer, A.S. \& Lewis, A.D. 1973. The Chañares (Argentina) Triassic reptile fauna XIX. Postcranial materials of the cynodonts Probelesodon and Probainognathus. Breviora, 407:1-26.

Rubert, R.R. 2003. Possibilidades de estabelecimento de um novo horizonte de correlação para o Triássico sul-rio-grandense. Programa de Pós-Graduação em Geociências, Universidade Federal do Rio Grande do Sul, Dissertação de Mestrado, 107 p.

Rubert, R.R. \& Schultz, C.L. 2004. Um novo horizonte de correlação para o Triássico Superior do Rio Grande do Sul. Pesquisas em Geociências, 31(1):71-88.

Schultz, C.L. \& Langer, M.C. 2000. Rincossauros - herbívoros cosmopolitas do Triássico. In: M. Holz \& L.F. De Ros (eds.) Paleontologia do Rio Grande do Sul, CIGO/UFRGS, p. 246-272.

Schultz, C.L. \& Soares, M.B. 2006. Proposta de nova denominação para a Cenozona de Ictidosauria, do Triássico Superior (Formação Caturrita) do Rio Grande do Sul. In: CONGRESSO BRASILEIRO DE PALEONTOLOGIA DE VERTEBRADOS, 5, 2006. Boletim de Resumos, Santa Maria, UFSM, p. 41.

Sues, H.D. \& Jenkins, F.A., Jr. 2006. The postcranial skeleton of Kayentatherium wellesi from the Lower Jurassic Kayenta Formation of Arizona and phylogenetic significance of postcranial features in tritylodontid cynodonts. In: M.T. Carrano; T.J. Gaudin; R.W. Blob \& J.R. Wible (eds.) Amniote Paleobiology: perspectives on the evolution of mammals, birds, and reptiles, The University of Chicago Press, p. 114-152.

Teixeira, A.M.S. 1982. Um novo cinodonte carnívoro (Probelesodon kitchingi sp. nov.) do Triássico do Rio Grande do Sul, Brasil. Comunicações do Museu de Ciências da PUCRGS, 24:1-31.

Teixeira, A.M.S. 1987. Novas observações osteológicas e taxonômicas sobre Massetognathus ochagaviae Barberena, 1981 (Reptilia, Therapsida, Cynodontia). Paula-Coutiana, 1:39-49.

Zerfass, H.; Lavina, E.L.; Schultz, C.L.; Garcia, A.J.V.; Faccini, U.F. \& Chemale, F., Jr. 2003. Sequence stratigraphy of continental Triassic strata of Southernmost Brazil: a contribution to Southwestern Gondwana palaeogeography and paleoclimate. Sedimentary Geology, 161:85-105.

Received in April, 2009; accepted in June, 2009. 